\title{
Por entre metáforas: um estudo comparado entre o Sermão da sexagésima e o sermão Pecadores nas mãos de um Deus irado
}

\author{
Francisco Pereira Smith Júnior* \\ Tiane Silva de Sousa**
}

Ao longo do tempo o cristianismo passou por diversas modificações, divisões e rupturas, ${ }^{1}$ resultando em uma grande diversidade de instituições religiosas na atualidade, cada uma com suas respectivas denominações e ramificações, com discursos e práticas próprias. Entretanto, independente de qual seja a instituição religiosa, como afirma Batista (2015, p. 265-266), o principal objetivo do cristianismo é converter pessoas, sua proposta é levar pessoas a abandonar o pecado e viver uma nova vida, evidentemente, uma vida em harmonia com os preceitos religiosos. Ainda segundo o autor mencionado, a doutrina da salvação é a temática do cristianismo desde os seus primórdios e envolve a eleição dos pecadores, a sua regeneração, a sua conversão e a sua santificação, além da necessidade da pregação fiel da palavra de deus, da fé, das boas obras e da perseverança dos santos e da necessidade do arrependimento.

Assim sendo e considerando que os autores contemplados neste estudo são dois grandes pregadores e oradores cristãos, embora de orientações opostas, sendo um do catolicismo e o outro do protestantismo, e observando o contexto histórico e social em que estão inseridos, épocas de ameaças às suas respectivas visões religiosas e de diminuição do número de pessoas convertidas, pretende-se, por meio da perspectiva da literatura comparada, confrontar as obras Sermão da sexagésima, de Padre Antônio Vieira, ${ }^{2}$ e Pecadores nas mãos de um Deus irado, de Jonathan

\footnotetext{
Doutor em ciências pelo Núcleo de Altos Estudos Amazônicos e professor da Faculdade de Letras, Campus Bragança, da Universidade Federal do Pará (UFPA), PA, Brasil. E-mail: fransmithj@gmail.com.

** Graduada em Letras - Língua Portuguesa. E-mail: tianesousaoz@gmail.com.

1 Referente aos acontecimentos históricos que deram origem aos diferentes segmentos do cristianismo, a divisão entre a Igreja Católica Apostólica Romana e a Ortodoxa e a reforma protestante, que originou as igrejas protestantes que, por sua vez, subdividiram-se em diversas ramificações ao longo do tempo.

2 Sacerdote jesuíta, Padre Antônio Vieira foi um importante escritor, orador, missionário e político, considerado a mais alta personalidade do barroco luso-brasileiro. Nascido em 1608, em Lisboa, veio para o Brasil aos seis anos de idade, mais especificamente para a Bahia, onde estudou no colégio dos jesuítas, ingressando na Companhia de Jesus em 1623 e ordenando-se em 1634. Desde
} 
Edwards,${ }^{3}$ com o intuito de evidenciar pontos de aproximação e de distanciamento no referente ao uso da metáfora como um dos principais recursos persuasivos utilizados por estes autores para o convencimento de seu público. Para isso, serão considerados aspectos como disposição e organização das construções metafóricas nos textos e os elementos a partir dos quais estas são construídas, sendo analisadas, ainda, as possíveis motivações para o seu uso, assim como suas implicações.

O desenvolvimento deste estudo se apoia no pensamento do comparativista René Wellek (apud CARVALHAL, 2006a), que se opõe aos clássicos estudos de fontes e influências, de causas e efeitos, que sem considerar a análise das obras em sua totalidade, ocupam-se apenas de dados extraliterários. Deste modo, Wellek propõe o abandono dos estudos que buscam evidenciar a influência de um texto sobre outro, dando maior importância ao primeiro em detrimento do segundo, e defende uma análise centrada no texto e não mais em dados externos, desejando substituir “o que considera 'passatempo de antiquado' ou 'cálculo de créditos e débitos nacionais' ou ainda 'mapeamento de rede de relações' por uma modalidade de análise sinônima de crítica" (CARVALHAL, 2006a, p. 37), adotando, assim, uma postura anti-historicista. Porém, como bem lembra Carvalhal:

muito cedo demonstrou ser um brilhante orador, iniciando sua carreira de pregador logo que se ordenou e alcançando, em pouco tempo, fama de orador culto e eloquente. Morreu na Bahia, aos quase noventa anos, em 1697 quando trabalhava na redação e publicação de suas obras (MoIsés, 2008; Bosi, 2006). Escreveu muitos sermões, dentre estes o Sermão pelo bom-sucesso das armas de Portugal contra as de Holanda, Sermão de Santo Antônio, Sermão da primeira dominga da quaresma e Sermão da sexagésima. O Sermão da Sexagésima é uma de suas obras mais conhecidas. Foi pregado em 1655, em Lisboa, na Capela Real (Bosi, 2006). Seguindo a estrutura clássica tripartite: introito (ou exórdio)em que o orador declara o plano a utilizar na análise do tema em pauta; desenvolvimento (ou argumento) em que são apresentados os prós e os contras da proposição e os exemplos que os sustentam e a peroração, em que o orador finaliza a prédica convocando os ouvintes à prática das virtudes que nela foram enaltecidas (MoIsÉs, 2008), este sermão divide-se em dez capítulos e aborda a questão da pouca eficiência da pregação católica na época, de modo que irá levantar uma série de possíveis motivos para o fato de esta não estar alcançando o seu objetivo. Para tanto, Padre Vieira utiliza como base a parábola do semeador, tirada do livro de Lucas, capítulo oito, relacionando, por meio da metáfora, o "pregar" ao "semear", analogia que ele irá desenvolver por meio de elaborados argumentos e estratégias discursivas, para mostra o porquê de a palavra de deus não estar produzindo frutos.

3 Jonathan Edwards foi um pastor, intelectual e teólogo do século XVIII. Considerado um dos maiores nomes da literatura colonial dos Estados Unidos e do puritanismo na América, nasceu em 1703 em East Windsor, Connecticut, e advém de uma família tradicionalmente religiosa, sendo seu pai e avô respeitados ministros puritanos da Nova Inglaterra. Homem muitíssimo instruído, possuidor de um grande senso de dever e fortemente influenciado por um ambiente puritano severo, Edwards dedicou sua vida à defesa do calvinismo rigoroso, ameaçado por forças liberais que surgiam à sua volta (MARSDEN, 2015; GoMES, 2009; VANSPANCKEREN, 1994). Dentre seus escritos estão o Diário, as Miscelâneas, Livre arbítrio e Fiel narrativa da surpreendente obra de Deus que descreve o avivamento ocorrido em Northampton e que é seu primeiro escrito sobre o movimento de avivamento da fé que ficou conhecido como o "Grande despertar", do qual se tornou um fervoroso defensor e teórico. Edwards faleceu em 1758, aos 54 anos, em decorrência de infecções causadas por varíola (MARSDEN, 2015). 
A literatura comparada, sendo uma atividade crítica, não necessita excluir o histórico (sem cair no historicismo), mas ao lidar amplamente com dados literários e extraliterários ela fornece à crítica literária, à historiografia literária e à teoria literária uma base fundamental. Todas essas disciplinas concorrem em conjunto para o estudo do literário, resguardada a especificidade de cada uma (CARvAlHAL, 2006a, p.39).

Desse modo, a literatura comparada tem também um caráter interdisciplinar, relacionando-se com outras áreas do conhecimento, explorando as diversas possibilidades de ligações da literatura com outras formas de expressão artística e outras formas de conhecimento, enriquecendo suas investigações.

Para Machado e Pageaux (2001, p. 11), a interdisciplinaridade proporciona não só o diálogo entre as literaturas e as culturas, mas também entre os métodos de abordagem do fato e dos textos literários, dependendo da natureza da questão levantada pelo investigador. Deste modo, não havendo um método específico a seguir, não haverá, também, uma maneira específica do comparativista questionar, uma maneira de estabelecer a relação entre os elementos escolhidos para a investigação.

Para este estudo, também se faz necessário entender a importância da intertextualidade como forma de dialogar com os textos a partir de uma lógica de infinitas possibilidades, em que o texto literário se conecta a novas formas de reflexões da teoria literária. De acordo com Carvalhal, a noção de intertextualidade é um dos princípios básicos da teoria textual e foi introduzida nos estudos literários por Julia Kristeva para caracterizar a produtividade textual a partir do conceito de dialogismo de M. Bakhtin que entende

a intertextualidade, cunhada e difundida por Kristeva, é explicada como uma propriedade do texto literário, que "se constrói como um mosaico de citações, como absorção e transformação de outro texto". Para ela, "em lugar da noção de intersubjetividade se instala a de intertextualidade e a linguagem poética se lê, ao menos, como dupla (CARVALHAL, 2006b, 127).

Assim, a teoria do texto está fundamentada em três grandes premissas: que a linguagem poética é a única infinitude do código, que o texto literário é duplo, "escrita/leitura" e que o texto literário se constitui como um feixe de conexões. Diante disso, segundo Carvalhal, o texto age em diálogo de várias escrituras, e o que era antes entendido numa relação individual (intersubjetiva) tornou-se coletivizado, isto é, as relações estabelecem-se no conjunto dos textos.

Por fim, traz-se a importância da tematologia para o estudo em questão, visto que as obras Sermão da sexagésima e o sermão Pecadores nas mãos de um Deus irado inserem-se no campo da temática religiosa. Para Machado e Pageaux (1982 apud Pires, 2007) o tema é tudo aquilo que pode ser tomado como elemento constitutivo e explicativo do texto literário, que ordena e permite produzir o texto, ou 
seja, é um princípio estruturante e organizador a partir do qual o texto se constrói. Para estes autores, há uma distinção entre tema e motivo, em que o segundo se contrapõe ao primeiro por ser tudo aquilo não intervém no plano da estruturação e da organização do texto, ou, como propõe Raymond Trousson (1988 apud PIRES, 2007) é um amplo conceito que designa quer uma certa atitude como, por exemplo, a revolta, quer uma situação de base e impessoal, na qual os atores ainda não foram individualizados, a exemplo de situações como a do homem entre duas mulheres, da oposição entre dois irmãos, entre pai e filho, da mulher abandonada, etc.

Segundo Pires (2007), Trousson atribui ao motivo um caráter mais geral, não literário, pois também interessa a outras áreas do conhecimento, como a psicanálise, e ao tema um caráter mais restrito, pois particulariza o motivo, que se torna literário. O tema seria o que estrutura, com sua especificidade, a obra literária, o poema, a tragédia, o conto. Desta forma, o motivo da rivalidade entre irmãos tornase tema quando se concretiza em histórias como a de Abel e Caim, por exemplo. Assim, o motivo, que a princípio é elemento não literário, por delimitar algumas situações e atitudes fundamentais é matéria da literatura e o tema, por sua vez é a cristalização e a particularização de um motivo, sendo sempre objeto literário, pois ele não existe senão a partir do momento em que o motivo se exprime numa obra.

Diante de tudo isso, "acentua-se, então, a mobilidade da literatura comparada como forma de investigação que se situa 'entre' os objetos que analisa, colocandoos em relação e explorando os nexos entre eles, além de suas especificidades”, implicando em "uma ampliação dos campos de pesquisa e à aquisição de competências” (CARVAlHal, 2006a, p. 74).

Nesse sentido, por um lado, a literatura comparada é a comparação da literatura com a própria literatura e, por outro, da literatura com as outras formas de expressão humana, resultando em uma forma de investigação que interroga os textos literários na interação com outros textos, literários ou não, e outras formas de expressão artísticas e culturais.

\section{Por entre metáforas: diálogos entre Edwards Vieira}

Edwards é fruto da sociedade colonial da Nova Inglaterra, construída sob os princípios da rígida doutrina puritana trazida por um pequeno grupo de imigrantes que chegou à Massachusetts em 1620. Esse grupo, de origem inglesa, deixou sua terra em virtude de perseguições religiosas, uma vez que como adeptos do protestantismo calvinista, renegavam o anglicanismo e o catolicismo, religiões predominantes na Inglaterra. Em terras americanas, esses imigrantes almejavam um novo começo para a história e sua religião. Por meio de um ideal de sociedade moldada por seus preceitos religiosos, de prosperidade e obediência às leis cristãs, foram os responsáveis pela primeira fase da identidade norte-americana, construindo não só escolas, igrejas e universidades, mas também uma ideia de América que vigora até os dias de hoje (Gomes, 2009). 
Embora os colonos tenham enfrentado um início de grandes dificuldades, com o passar do tempo alcançaram prosperidade material, fruto de seus valores éticos e religiosos de amor ao trabalho, disciplina de vida e rejeição aos vícios. No entanto, no tempo de Jonathan Edwards, esses valores encontravam-se um tanto enfraquecidos, junto com a prosperidade houve um declínio do fervor religioso entre as novas gerações. Além disso, no início do século XVIII, a sociedade colonial norte-americana experimentava uma crescente influência das ideologias vindas da Europa, as ideias iluministas adentravam a Nova Inglaterra, causando mudanças de pensamento e atitude que desafiavam não somente as convicções evangélicas e reformadas dos puritanos, mas também os fundamentos do cristianismo histórico, de modo que muitos pensadores rejeitavam a ideia de uma humanidade pecadora que estava sob o julgamento de um deus justo (MATOs, 1998).

Foi em meio a esse confronto entre novas e velhas ideias, que dividiam a sociedade entre conservadores e liberais, que Edwards alcançou a vida adulta. Com grande sensibilidade intelectual, este religioso levou a sério todas as realidades e questões de seu tempo. Em suas reflexões e prática defrontou-se com ameaças à fé reformada e empenhou-se em combatê-las. Para tanto, buscou não somente resgatar o que havia de positivo na experiência e contribuição dos puritanos de outrora, mas preocupou-se em fazer isso de maneira intelectualmente defensável, no intuito de demonstrar que não havia qualquer conflito intransponível entre fé e razão (MATOS, 1998), utilizando-se, deste modo, da própria linguagem intelectual da época para defender aquilo que acreditava.

Empenhado no regaste do fervor da fé protestante, Jonathan Edwards recebeu com alegria e esperança o avivamento que ocorreu em sua igreja, em Northampton, e mais tarde, em maiores proporções, aqueles ocorridos em outras partes da nova Inglaterra e das outras colônias americanas. Os avivamentos na Nova Inglaterra foram parte de um movimento organizado em todo o mundo protestante que reunia repostas comuns à perda de vitalidade da religiosidade. Caracterizouse pela ida de pastores de cidade em cidade para pregar sermões que, comumente, causavam grande comoção e exaltação entre os fiéis e, assim, renovavam sua fé. Edwards foi um dos maiores nomes desse movimento na América e tem como um de seus sermões mais representativos desse momento Pecadores nas mãos de um Deus irado.

O sermão Pecadores nas mãos de um Deus irado foi pregado em Enfield, Connecticut, no ano 1741 e costuma ser a obra mais conhecida de Jonathan Edwards. Como a maioria de seus sermões, Pecadores segue a composição clássica do sermão puritano: no primeiro momento a passagem bíblica, que serve de tópico central do trabalho escrito; na sequência é apresentada a doutrina, que corresponde à lição que deve ser apreendida do texto; a terceira parte é as das razões, com fatos ou provas que confirmam a doutrina e por último, apresentam-se os usos, a aplicação da doutrina por parte dos fiéis (GOMEs, 2009, p. 24). 
Utilizando-se desse formato clássico, Edwards divide seu texto em dois momentos, no primeiro aborda a ira e a justiça de Deus e na segunda a misericórdia divina por meio da qual o homem será resgatado, desde que se arrependa verdadeiramente de seus pecados. De acordo com Anderson Gomes (2009) e George Marsden (2015), o autor utiliza-se de um poderoso recurso de imagística em torno da ira e do poder de deus, de modo que este se apresenta como um juiz perfeitamente justo e corretamente indignado com a rebeldia dos homens contra o seu amor, podendo a qualquer momento lançá-los nas fornalhas do inferno, mas, ao mesmo tempo, restringe misericordiosamente sua punição severa, por algum tempo, para dar aos homens a oportunidade de se redimirem, enfatizando, assim, a tensão entre o julgamento e a misericórdia.

Como lembra Marsden (2015), Pecadores é habitualmente citado como exemplo de pregação do fogo do inferno na América primitiva, no entanto, não se pode limitá-lo apenas a essa visão, uma vez que os pregadores dessa época pregavam sobre o inferno porque acreditavam que este era uma realidade terrível sobre a qual as pessoas precisavam ser alertadas, de modo que ajudá-las era uma coisa amável a ser feita. Além disso, como chama atenção Gomes (2009), ainda que Jonathan Edwards seja tomado como o estereótipo de rígido pregador puritano que incutia o medo e a culpa nos fiéis por meio de sermões exagerados, seus textos também partilhavam da herança racionalista de John Locke e Isaac Newton, acreditando que o homem pode melhorar e aperfeiçoar o seu caráter.

Embora Pecadores nas mãos de um Deus irado tenha causado grande comoção quando foi pregado em Enfield, Edwards não usou uma voz estridente ou movimentos exaltados para proferi-lo, como era comum nos avivamentos da época. Sua voz era fraca, geralmente usava poucos gestos e fazia pouco contato visual com seu público. No entanto, falava com firmeza e convicção na mensagem que expunha. Seus sermões eram penetrantes graças a combinação de lógica e de intensidade espiritual, que aliadas à linguagem dramática empregada em Pecadores demonstrou ser poderosa e eficaz no convencimento de seus ouvintes (MARSDEN, 2015).

Em Pecadores nas mãos de um Deus irado, seguindo o modelo clássico do sermão puritano, o texto é iniciado com uma passagem bíblica: "Ao tempo em que resvalar o seu pé" (Deuteronômio 32:25) que é explicada pelo pregador como estando relacionada à iminente punição e destruição a que os israelitas ímpios (pecadores) estavam expostos. Partindo disso, Jonathan Edwards irá construir sua exposição em torno da ira e do poder de deus contra os pecadores, que por insistirem em viver no pecado são merecedores do inferno. Desta forma, o pregador objetiva alertar as pessoas da terrível realidade do inferno e, para tanto, utiliza como uma de suas mais fortes estratégias persuasivas uma série de metáforas para mostrar o quão irado Deus está com os pecadores e o quão horrível é ser condenado ao inferno. Sendo assim, o uso das metáforas para pregar foi identificado no sermão puritano e estas foram classificadas quanto à ênfase nos elementos em torno do qual o texto é construído. A representação da ira de Deus: 
A espada da justiça Divina está a todo momento se revolvendo sobre suas cabeças. E não é nada, senão, a misericórdia livre de Deus e a Sua mera boa vontade, que a segura (EDwARDs, 2015, p. 4).

O arco da ira de Deus está curvado, e a flecha ajustada no cordel. A justiça mira a flecha nos seus corações, e estica o arco, e nada, a não ser a mera boa vontade de Deus, de um Deus irado, sem qualquer promessa ou obrigação alguma, é que impede a flecha de a qualquer instante beber o sangue de vocês (EDwARDs, 2015, p. 9).

A representação do inferno:

O abismo está preparado, o fogo está pronto, o forno já está pronto quente, pronto para recebê-los; as chamas ora rugem e brilham. A espada reluzente está afiada e suspensa sobre eles, o abismo abriu sua boca debaixo deles (EDWARDS, 2015, p. 5).

O diabo espera por eles, o inferno escancara sua boca por eles, as chamas se ajuntam e queimam ardentemente à sua espera, para engoli-los (EDWARDS, 2015, p. 8).

A condição do pecador:

Os não convertidos andam sobre o abismo do inferno em uma superfície podre, e há inúmeros lugares nela que são frágeis e não suportarão seus pesos, e estes lugares não percebidos. As flechas da morte voam invisíveis ao meio-dia, a vista mais acurada não as vê. [...] Suas iniquidades os tornam tão pesados quanto o chumbo e os empurram para baixo com grande peso e pressão em direção ao inferno (EDWARDS, 2015, p. 8).

O pecado é a ruína e a miséria da alma. [...] A corrupção do coração humano é ilimitada e desmedida em sua fúria. Enquanto os ímpios vivem aqui, é como o fogo preso pelas restrições de Deus, de outro modo, se fosse deixada livre, poria em chamas o curso da natureza (EDWARDS, 2015, p. 6).

O Sermão da Sexagésima também é iniciado com uma passagem bíblica: "A semente é a palavra de Deus" (Lucas 8:11) correspondente à parábola do semeador, a partir da qual Padre Vieira introduz o assunto do sermão: a pouca eficiência da pregação católica, e relaciona o pregar ao semear. De forma semelhante ao que ocorre no sermão puritano, as metáforas são construídas em torno de alguns elementos ou núcleos, porém estão organizadas de acordo com os capítulos da obra, com exceção para a metáfora que equipara o pregar ao semear, diferente do texto de Edwards, em que as metáforas se encontram divididas quanto ao elemento em torno do qual se estruturam, mas estão dispersas quanto à disposição textual.

No primeiro capítulo, referente às dificuldades que o pregador encontra em seu ofício: 
O ano tem tempo para as flores e tempo para os frutos. Por que não terá também o seu outono a vida? As flores, umas caem, outras secas, outras murcham, outras leva-as o vento; aquelas poucas que se pegam ao tronco e se convertem em fruto, só essas são as venturosas, só essas são as discretas, só essas são as que duram, só essas são as que aproveitam, só essas são as que sustentam o mundo. Será bem que o mundo morra à fome? Será bem que os últimos dias se passem em flores? Não será bem, nem Deus quer que seja, nem há de ser (VIEIRA, 1994, p. 19).

O segundo capítulo e a explicação da parábola do semeador:

O trigo que semeou o pregador evangélico, diz Cristo, que é a palavra de Deus. Os espinhos, as pedras, o caminho e a terra boa em que o trigo caiu, são os diversos corações dos homens (VIEIRA, 1994, p. 19).

No terceiro capítulo, o referente à busca pelo culpado do não frutificar da palavra de deus:

Que coisa é a conversão de uma alma, senão entrar um homem dentro em si e ver-se a si mesmo? Para esta vista são necessários olhos, é necessária luz e é necessário espelho. O pregador concorre com o espelho, que é a doutrina; Deus concorre com a luz, que é a graça; o homem concorre com os olhos, que é o conhecimento (VIEIRA, 1994, p. 21-22).

Os piores ouvintes que há na Igreja de Deus são as pedras e os espinhos. E por quê? Os espinhos por agudos, as pedras por duras. Ouvintes de entendimentos agudos, e ouvintes de vontades endurecidas, são os piores que há (VIEIRA, 1994, p. 24).

A pessoa do pregador, capítulo quatro:

Palavras sem obras são tiro sem bala: atroam, mas não ferem (VIEIRA, 1994, p. 27).

Se quando os ouvintes percebem os nossos conceitos, têm diante dos olhos as nossas manchas, como hão de conceber virtudes? (VIEIRA, 1994, p. 30).

Sobre o estilo usado nos sermões: "suposto que o céu é pregador, deve de ter sermões e deve de ter palavras. [...] E quais são estes sermões e estas palavras do céu? As palavras são as estrelas, os sermões são a composição, a ordem, a harmonia e o curso delas" (VIEIRA, 1994, p. 33). Com relação ao assunto do sermão: 
Se uma nau fizesse um bordo para o norte, outro para sul, outro para leste, outro para oeste, como poderia fazer viagem? Por isso nos púlpitos se trabalha tanto e se navega tão pouco. Um assunto vai para um vento, outro assunto vai para outro vento; que se há de colher senão vento? (VIEIRA, 1994, p.38).

Uma árvore tem raízes, tem troncos, tem ramos, tem folhas, tem varas, tem flores, tem frutos. Assim há de ser o sermão: há de ter raizes fortes e sólidas, porque há de ser fundado no Evangelho; há de ter um tronco, porque há de ter um só assunto e tratar uma só matéria; deste tronco hão de nascer diversos ramos, que são diversos discursos, mas nascidos da mesma matéria e continuados nela (VIEIRA, 1994, p. 39).

No capítulo sete, Vieira constrói as metáforas sobre a ciência ou o conhecimento do pregador. "Fez Cristo aos apóstolos pescadores de homens, que foi ordená-los de pregadores; e que faziam os Apóstolos? Diz o texto, que estavam "refazendo as redes suas"; eram as redes dos apóstolos, e não eram alheias. [...]. Desta maneira eram as redes suas; e porque desta maneira eram suas, por isso eram redes de pescadores que haviam de pescar homens. Com redes alheias, feitas por mãos alheias, podem-se pescar peixes, homens não se podem pescar (VIEIRA, 1994, p. 43). Em seguida, no oitavo capítulo, o autor trata da voz usada na pregação:

A nuvem tem relâmpago, tem trovão e tem raio: relâmpago para os olhos trovão para os ouvidos, raio para o coração; com o relâmpago alumia, com o trovão assombra, com o raio mata. Mas o raio fere a um, o relâmpago a muitos, o trovão a todos. Assim há de ser a voz do pregador - um trovão do Céu que assombre e faça tremer o mundo (VIEIRA, 1994, p. 48).

Já sobre o sentido em que as escrituras bíblicas são utilizadas, Vieira aborda no nono capítulo do Sermão:

O pináculo do templo é o púlpito, porque é o lugar mais alto dele. $\mathrm{O}$ diabo tentou a Cristo no deserto, tentou-o no monte, tentou-o no templo; no deserto tentou-o com a gula; no monte tentou-o com a ambição, no templo tentou-o com as Escrituras mal interpretadas, e essa é a tentação de que mais padece hoje a Igreja (VIEIRA, 1994, p. 51).

Fábula tem duas significações: quer dizer fingimento, e quer dizer comédia; e tudo são muitas pregações deste tempo. São fingimento, porque são subtilezas e pensamentos aéreos sem fundamento de verdade; são comédia, porque os ouvintes vêm à pregação como à comédia, e há pregadores que vêm ao púlpito como comediantes (VIEIRA, 1994, p. 55).

Por fim, no décimo capítulo Vieira trata do gosto dos ouvintes em relação ao que é pregado: "Que médico há que repare no gesto do enfermo, quando trata 
de lhe dar saúde? Sarem, e não gostem; salvem-se e amargue-lhes, que para isso somos médicos das almas" (VIEIRA, 1994, p. 59).

Tal diferença de disposição e organização das metáforas nos textos implica na adoção de diferentes estratégias de convencimento pelos autores, às quais as metáforas estão subordinadas, que por sua vez almejam o alcance de objetivos distintos. Parece-nos que no caso do sermão puritano, a dispersão das metáforas no texto serve a um recurso de convencimento baseado na constante repetição e reiteração da mensagem que está sendo transmitida: o quão deus está irado com os pecadores, podendo mandá-los ao inferno a qualquer momento. Já no caso do sermão católico, indica-nos a construção gradativa de um raciocínio, ou melhor, de vários que conduzem a um ponto comum: a responsabilização do pregador pela ineficiência da pregação e no que consiste sua culpa. Este raciocínio é compreendido pela retórica como sendo dialético, pois, aponta para mais de uma conclusão possível, mas, pelo modo como são formuladas as hipóteses, acaba por indicar a mais aceitável (CiTELLI, 2002).

Em Pecadores, o raciocínio que parece prevalecer, em contraste com o anterior, é o apodítico, que possuí tom de verdade inquestionável, de modo que a "argumentação é realizada com tal grau de fechamento que não resta ao receptor qualquer dúvida quanto à verdade do emissor" (Citelli, 2002, p. 18), por exemplo: "O mundo os vomitaria, não fosse a mão soberana daquele que o sujeitou na esperança [da redenção]" e "eis as nuvens negras da ira de Deus pairando agora sobre suas cabeças, carregadas de terrível tempestade, e cheia de trovões, e não fosse a mão restringente de Deus, elas imediatamente arrebentariam sobre vocês" (EDWARDs, 2015, p. 9). Considerando que os textos aqui contemplados são dois sermões cristãos, portanto, textos dentro da temática religiosa, é possível entender a diferença de organização e construção dos textos como decorrência do contraste social e cultural em que estes foram escritos, pois como afirmam Machado e Pageaux:

O estudo do tema obriga o investigador a empreender duas leituras simultâneas dos textos analisados: em primeiro lugar, o texto é, no plano da criação literária, um universo coerente; em segundo lugar, a procura dum sentido deve ser feita no interior do texto e também no conjunto do campo cultural a que esse texto pertence. [...] O estudo temático revela, afinal, claramente, as duas fases indissociáveis da investigação literária: o estudo do funcionamento interno dum texto (dum tema num texto, a leitura contribuindo para pôr em evidência, para reconstruir um conjunto de funções) e o estudo da função social e cultural desse mesmo texto (Machado; Pageux, 2001, p.94).

Assim, a forma de escrita e de pregação de Edwards e Vieira devem ser entendidas como parte integrante de um contexto histórico, social e cultural, que irá influenciá-las. Desse modo, Pecadores segue o modelo de exposição adotada pelo movimento de avivamentos ocorridos na Nova Inglaterra, marcados por exposi- 
ções intensas, exaltadas, e frequentemente sobre o inferno, assim como um modelo de linguagem estabelecida como ideal pelos puritanos, prezando pela exposição simples e direta em seus sermões, pois a mensagem precisava ser entendida facilmente, sem desvio do sentido em que estava sendo exposta, que por sua vez, deveria ser fiel às escrituras sagradas. O que explica a existência de uma única linha de raciocínio no sermão de Edwards, sem jogos de sentido, porém lógica, enfatizando sempre a mesma ideia. Do mesmo modo, Padre Antônio Vieira reproduz o modelo estético e de pensamento de seu tempo, o barroco, adotando a tendência conceptista em seus escritos: predomínio da razão, da lógica e da discursividade, o que explica os múltiplos raciocínios empregados no Sexagésima.

Além da questão da disposição das construções metafóricas no texto, outro ponto a ser destacado é o processo de construção das metáforas e os elementos que as constitui. No sermão puritano, observa-se que as metáforas, em sua maioria, são construídas a partir de elementos que normalmente causam temor ou medo nas pessoas, tais como tempestades, trovões, nuvens negras, o fogo com suas chamas e calor, assim como as águas represadas com seu potencial de destruição, além de objetos como espadas e flechas que podem ser utilizados para ameaçar ou ferir alguém. Com base nos conceitos de domínio fonte, domínio alvo e mapeamentos elaborados por Lakoff e Johnson (apud Vieira, 2015), podemos dizer que o autor estabelece uma série de correspondências entre esses elementos, que correspondem ao domínio alvo, a ira de deus e o inferno, referentes ao domínio fonte, para demonstrar o quanto deus é poderoso e o quão destrutiva e ameaçadora é a sua ira; assim como quão pavoroso é o inferno para, deste modo, levar os seus ouvintes/leitores a temerem essas duas coisas e obrigá-los a uma mudança de vida. A necessidade dessa mudança será enfatizada pela posição de insegurança em que o pecador será colocado no texto e que é expressa, por exemplo, pelo trecho:

Os não convertidos andam sobre o abismo do inferno em uma superfície podre, e há inúmeros lugares nela que são frágeis e não suportarão seus pesos, e estes lugares não são percebidos. As flechas da morte voam invisíveis ao meio-dia, a vista mais acurada não as vê (EDWARDS, 2015, p. 6).

Neste trecho, a situação de fragilidade e instabilidade do pecador é expressa pela construção metafórica "andam sobre o abismo do inferno em uma superfície podre" e é reforçada por "as flechas da morte voam invisíveis ao meio-dia", o que demonstra que as pessoas não convertidas estão em constante risco de serem mandadas ao inferno e caso venham a morrer inesperadamente, não poderão ter suas almas salvas. Sendo assim, as metáforas colaboram amplamente para a construção de uma imagem de terror e pavor em torno da ira de deus e do inferno, causando medo e temor nas pessoas e, consequentemente, levando-as a submissão aos ditames da religião.

Já no sermão católico, as metáforas não servirão a uma estratégia de convencimento baseada no medo e no temor, mas a um elaborado e complexo processo argumentativo pelo qual o pregador objetiva persuadir não pela emoção, mas pela 
razão, envolvendo o ouvinte/leitor em um jogo de raciocínios que levam a conclusões únicas e inquestionáveis, pois, a argumentação não deixa "pontas soltas":

Uma árvore tem raízes, tem troncos, tem ramos, tem folhas, tem varas, tem flores, tem frutos. Assim há de ser o sermão: há de ter raízes fortes e sólidas, porque há de ser fundado no Evangelho; há de ter um tronco, porque há de ter um só assunto e tratar uma só matéria; deste tronco hão de nascer diversos ramos, que são diversos discursos, mas nascidos da mesma matéria e continuados nela (VIEIRA, 1994, p. 39).

Deste modo, os elementos a partir dos quais as metáforas são construídas serão bastante diversificados, pois servirão a objetivos diferentes ao longo do texto, de acordo com os diferentes capítulos em que este se divide, sendo utilizados, por exemplo, elementos da natureza como as estações do ano, a estrutura de uma árvore (tronco, galhos, folhas, fruto, etc.), atividades laborais como a caça, o semear, a pesca e a navegação, entre vários outros, o que fará com que as construções metafóricas no Sexagésima tenham muito mais a intenção de esclarecimento, explicação ou ilustração do que está sendo proposto, do que de ameaça de punição.

Novamente, essa diferença entre os sermões se dá em virtude do jogo de oposições entre o contexto histórico e social em que foram produzidos os textos. No entanto, deve-se ampliar essa reflexão e considerar o nível ideológico das obras, uma vez que o texto literário "pode ser lido e tido como um lugar de cristalização de um esquema ou modelo ideológico graças ao qual se pode, mais ou menos diretamente, reconstruir o sistema e valores duma sociedade ou duma ideologia" (Machado; Pageaux, 2001, p. 147). Desse modo, entende-se que a escolha dos elementos a partir dos quais as metáforas são construídas em ambos os textos se deu com base na ideologia religiosa de cada um de seus autores.

Edwards crê na rígida doutrina puritana do homem naturalmente pecador e de um Deus punitivo, cujo poder está sempre em contraste com a devassidão e a maldade humana, assim como na unicidade dos fatos, na clara distinção do que é certo e errado (Gomes, 2009). Tendo isso em vista e considerando o contexto dos avivamentos, no qual esses princípios foram reafirmados, além da função de Edwards enquanto líder religioso, a de converter e ajudar pessoas a alcançar a salvação, a escolha de elementos que causam medo e temor como base das metáforas em Pecadores é justificada pela necessidade puritana de conscientizar os fiéis sobre o imensurável poder de Deus e a realidade do inferno.

De forma semelhante, a escolha desses elementos em Sexagésima pode ser entendida de acordo com a atuação de Padre Antônio Vieira enquanto sacerdote jesuíta. Os jesuítas tinham como missão a manutenção do catolicismo frente à ameaça reformista, por meio do ensino de seus dogmas, valores e princípios, de modo que suas pregações tinham por base uma função pedagógica. Assim, Vieira, tendo sido um dos principais representantes da pregação jesuítica, preza pela facilitação 
do entendimento do que está sendo ensinado, traduz o conteúdo dogmático em uma linguagem acessível e cativante, de forma que as metáforas em seu texto servem para se fazer compreender e, consequentemente, para fazer crer.

Outro ponto referente ao uso das metáforas nos sermões aqui estudados diz respeito à relação entre estas e as referências bíblicas presentes nos textos. Por serem textos religiosos cristãos, passagens bíblicas ou menção a elas são muito presentes em suas composições e servem para embasar e validar aquilo que o pregador diz, pois, "a voz de Deus plasmará as demais vozes" (Citelli, 2007, p.48). Posto isso, é possível observar que nos dois textos, em grande parte, a relação mencionada é de complementariedade, no sentido de que uma reforça a ideia apresentada pela outra.

No sermão puritano, por exemplo, é possível notar várias passagens bíblicas que trazem a ideia de um deus severo e punidor, que aniquila os seus inimigos, o que, juntamente com a utilização de metáforas construídas em torno da representação da ira de deus, resulta em um poderoso recurso de imagística que pode ter um grande impacto sobre aqueles que ouvem/leem o sermão. Essa relação de complementariedade pode ser estabelecida pela proximidade, mas, também, pela distância. $\mathrm{O}$ primeiro caso corresponde às passagens bíblicas e às metáforas que estão próximas no texto, dispostas uma após a outra e que se são empregadas na construção de um mesmo sentindo ou ideia, como nos trechos:

Deus não lhes terá outro uso, a não ser fazer com que sofram a miséria. Continuarão a existir sem nenhum outro propósito; pois serão um vaso de ira preparado para a destruição; e não haverá outro uso para esse vaso, senão ser cheio de ira. Deus estará tão longe de apiedar-se de vocês quando clamarem a Ele, que apenas "rirá e zombará" (Provérbios 1:25-26) (EDWARDS, 2015, p.12).

A justiça Divina fala acerca da árvore que produz uvas como as de Sodoma (Lucas 13:7). “Corta-a; por que ocupa ainda a terra inutilmente”. A espada da justiça Divina está a todo momento se revolvendo sobre suas cabeças, e não é nada, senão a mão da misericórdia livre de Deus e a Sua mera vontade, que a segura (EDwARDS, 2015, p.4).

Percebe-se que nestes trechos, metáforas e citações bíblicas se complementam e deixam mais forte e evidente a ideia que se deseja passar aos fiéis: a de que os não convertidos estão destinados a sofrer a ira divina. No primeiro caso, são comparados a um vaso destinado a ser cheio da ira de deus, ou seja, deus voltará todo o seu poder e ira contra os pecadores e não terá piedade deles, ideia que é reforçada pela citação, e, no segundo, comparados a uma árvore que não produz bons frutos são ameaçados de serem destruídos pela justiça divina, representada por uma espada que está pronta para golpeá-los a qualquer momento. 
O segundo caso, corresponde àquelas metáforas e passagens bíblicas que se encontram distantes no texto, mas que reforçam a ideia como se observa, por exemplo, no trecho:

É à ferocidade de Sua ira que você está exposto. Lemos com frequência acerca da ira de Deus; Isaías 59:18: Conforme forem as obras deles, assim será a sua retribuição, furor aos seus adversários". Assim, Isaías 66:15: "Porque, eis que o Senhor virá com fogo; e os seus carros como um torvelinho; para tornar a sua ira em furor, e a sua repreensão em chamas de fogo". Também em muitos outros lugares. Assim, lemos sobre o lugar do vinho do furor e da ira do Deus Todo-Poderoso (Apocalipse 19:15) (EDwARDs, 2015, p.11).

Nota-se que as citações bíblicas que constitui este trecho vão ao encontro das metáforas de representação da ira de deus e colaboram para a construção da imagem de um deus poderoso, justo e punidor, cuja ira deve ser temida. O mesmo ocorrerá com metáforas e passagens bíblicas que falam a respeito do inferno e da condição pecador. No Sermão da Sexagésima, essa relação de complementariedade também se faz presente, conforme se pode observar nos trechos a seguir:

Antigamente convertia-se o Mundo, hoje por que se não converte ninguém? Porque hoje pregam-se palavras e pensamentos, antigamente pregavam-se palavras e obras. Palavras sem obras são tiro sem bala: atroam, mas não ferem. A funda de Davi derribou o gigante, mas não o derribou com o estalo, senão com a pedra: infixus est lapis in fronte ejus [a pedra acertou sua cabeça]. As vozes da harpa de Davi lançavam fora os demônios do corpo de Saul, mas não eram vozes pronunciadas com a boca, eram vozes formadas com a mão: Davidtollebatcitharam, et percutiebatmanu sua [Davi tomava a harpa e tocava-a com sua mão] (VIEIRA, 1994, p. 27).

Se os ouvintes ouvem uma coisa e vêem outra, como se hão de converter? Jacó punha as varas manchadas diante das ovelhas quando concebiam, e daqui procedia que os cordeiros nasciam manchados [E concebia o rebanho diante das varas, e as ovelhas davam crias listradas, salpicadas e manchadas - Gênesis, XXX, 39]. Se quando os ouvintes percebem os nossos conceitos, têm diante dos olhos as nossas manchas, como hão de conceber virtudes? (VIEIRA, 1994, p. 30).

Nestes trechos, Padre Antônio Vieira enfatiza a necessidade de os pregadores terem boas obras e darem exemplo de boa conduta, pois apenas as palavras não são suficientes para converter as pessoas. "As palavras entram pelos ouvidos, as obras entram pelos olhos, e a nossa alma rende-se muito mais pelos olhos que pelos ouvidos" (VIEIRA, 1994, p. 28). Observa-se que nestas passagens, à semelhança dos exemplos do sermão puritano, metáforas e citações bíblicas trabalham juntas para a construção de uma mesma ideia e dão consistência ao argumento de que 
somente o uso de palavras não converte ninguém, pois servem de exemplificação e comprovação.

A correspondência entre metáforas e passagens bíblicas estabelecida nos sermões configura uma relação de intertextualidade, em que o texto bíblico é incorporado ao texto construído pelos pregadores, seja por meio da simples citação ou da reelaboração do conteúdo assimilado. Assim, "o texto ressalta sua natureza heterotextual, sendo penetrado de alteridade, construído de outras palavras além das suas próprias" (CARVAlHAL, 2006, 127). Nesse sentido, Roland Barthes (1973 apud Pageaux, 2011, p. 184) afirma que "todo texto é um 'intertexto' feito de outros textos, presentes em diversos níveis e patamares”. Assim sendo, entende-se que Vieira e Edwards constroem sua fala a partir do texto bíblico como forma de fundamentar suas proposições, pois o que dizem não são palavras suas, mas a palavra de deus e, portanto, a verdade.

Ainda a respeito da relação entre metáforas e o texto bíblico no sermão católico, nota-se que no texto vieiriano algumas metáforas são construídas a partir de elementos constituintes de passagem bíblicas, de modo que a relação entre elas não será de simples complementação ou colaboração, mas de uma ligação mais íntima, de um entrelaçamento mais profundo, mais complexo. Tal relação pode ser observada nas correspondências que o autor estabelece, por exemplo, entre a parábola do semeador e o trabalho do pregador, em que o semear é o pregar, o semeador o pregador, o trigo a palavra de deus, as pedras; os espinhos e as aves representam as dificuldades enfrentadas pelos pregadores. Todas essas ligações são exploradas pelo autor para levantar a questão da pouca eficiência da pregação católica em seu tempo e para desenvolver os argumentos que buscam responsabilizar o pregador pelo insucesso da pregação. Outro exemplo pode ser observado na metáfora que compara o pináculo do templo ao púlpito, em que as tentativas do diabo em persuadir Jesus utilizando as escrituras sagradas em sentido distorcido são comparadas às pregações feitas em seu tempo. Essas relações nos parecem ter uma maior influência sobre os ouvintes/leitores, pois estabelecem fortes correspondências entre o texto bíblico e a realidade.

Essa particularidade do texto vieiriano pode ser explicada pela propriedade seletiva da intertextualidade, "pois a absorção de elementos alheios responde a uma necessidade particular" (CARVALHAL, 2006, p. 128), de modo que a escolha do texto assimilado e a forma com que este é inserido no novo texto dependerão da intenção de quem escreve. Assim, Vieira, no intento de provar a culpa do pregador, não só faz referência ao texto bíblico, mas constrói um novo sentido para ele, um sentido em que as escrituras sagradas e a realidade, mais especificamente a realidade do pregador de sua época, se confundem. Com isso, percebe-se que, tanto no sermão puritano quanto no sermão católico, as metáforas em colaboração com passagens bíblicas tornam-se poderosas ferramentas de persuasão, pois, por um lado têm-se as construções metafóricas que ajudam a compreender e a apreender o que está sendo proposto, além de dar maior expressividade à mensagem e exer- 
cer uma maior influência sobre o público, em virtude das funções cognitiva, emotiva e conativa. Por outro, tem-se o texto bíblico que, por ser considerada a palavra de deus, é colocado como verdade absoluta e inquestionável e, portanto, valida aquilo que o pregador diz.

\section{Considerações finais}

Como foi demonstrado ao longo deste estudo, o discurso religioso, mais especificamente o discurso religioso cristão, tem como objetivo primordial converter pessoas, sendo, portanto, naturalmente persuasivo. Partindo desse pressuposto e considerando que as obras trabalhadas são de dois grandes pregadores cristãos, pretendeu-se evidenciar pontos de aproximação e de distanciamento no referente uso da metáfora como um dos principais recursos persuasivos utilizados para o convencimento do público.

Com este objetivo em vista, buscou-se, no primeiro momento, delinear o campo de estudos no qual este trabalho se apoia, a literatura comparada, e posteriormente definir o discurso religioso, ressaltando seu caráter persuasivo, além de discorrer acerca de algumas teorias da metáfora, a fim de demostrar sua importância para a produção e a compreensão do sentido e, consequentemente, para as pretensões doutrinárias do discurso religioso. $\mathrm{Na}$ análise das obras, empreendeu-se a investigação em dois sentidos, o primeiro referente à estrutura dos textos, que nos permitiu identificar o modo como as metáforas estão dispostas nos textos, os elementos a partir dos quais são construídas, assim como sua relação com trechos ou passagens bíblicas. Já o segundo diz respeito a consideração do texto nas suas relações com o contexto histórico, social e cultural, que nos permitiu não somente compreender o modo como as metáforas se estruturam e produzem sentido no nível interno das obras, mas também o porquê de terem sido utilizadas da forma como foram, o que nos faz compreender sua importante função social exercida sobre a sociedade de suas respectivas épocas.

\section{Referências}

Batista, Mário Sérgio. "Linguagem e religião": discurso persuasivo. Ciências da Religião: história e sociedade. São Paulo, v. 13, n. 2, p. 256-275, jul./dez. 2015. Disponível em: http://editorarevistas.mackenzie.br/index.php/cr/article/download/ 8894/6123. Acesso em: o2 fev. 2019.

Bosı, Alfredo. História concisa da literatura brasileira. 43 ed. São Paulo: Cultrix, 2006

Carvalhal, Tânia Franco. Literatura Comparada. 4 ed. rev. e ampliada. São Paulo: Ática, $2006^{\mathrm{a}}$. 
Citelli, Adilson. Linguagem e persuasão. 15 ed. São Paulo: Ática, 2002. Disponível em: https://edisciplinas.usp.br/pluginfile.php/4234777/mod_resource/content/ 1/Livro\%20Citelli.pdf. Acesso em: 2 fevereiro 2019.

Edwards, Jonathan. Pecadores nas mãos de um Deus irado. Trad. Tiago Cunha, 2015. Disponível em: https://oestandartedecristo.com/2015/12/o8/pecadores-nas-maosde-um-deus-irado-jonathan-edwards/. Acesso em: 13 dezembro 2018.

Gomes, Anderson Soares. Literatura norte-americana. Curitiba, PR: IESD Brasil, 2009, p. 11-27. Disponível em: https://docplayer.com.br/10849354-Literaturanorte-americana.html. Acesso em: 15 janeiro 2019.

Machado, Álvaro Manuel; Pageaux, Daniel-Henri. Da Literatura Comparada à Teoria da Literatura. 2 ed. rev. aum. Lisboa: Presença, 2001.

MARsdem, George M. A breve vida de fonathan Edwards. São José dos Campos, SP: Fiel, 2015. EPUB.

Massaud, Moisés. A literatura portuguesa. 35 ed. ver. atual. São Paulo: Cultrix, 2008.

Matos, Aderi S. Jonathan Edwards: teólogo do coração e do intelecto. Fides Reformata. [S.l], v. 3, n. 1, 1998. Disponível em: https://docplayer.com.br/15803516Jonathan-edwards-teologo-do-coracao-e-do-intelecto.html. Acesso em: 24 janeiro 2019.

Pageaux, Daniel-Henri. Musas na encruzilhada: ensaios de Literatura comparada. São Paulo: Hucitec; Santa Maria/RS: UFSM, 2011.

Pires, Antônio Donizeti. Lugares-comuns da lírica, ontem e hoje. Linguagem Estudos e Pesquisas, Catalão, v. 10-11, 2007.

VANSPANCKeren, Kathryn. Literatura americana. [S.I]: Departamento de Estado dos Estados Unidos da América, 1994. Disponível em: https://static.america.gov/ uploads/sites/8/2016/o5/Outline-of-AmericanLiterature_Portuguese_Lo-Res.pdf. Acesso em: 15 janeiro 2019 .

Vieira, Antônio. Sermão da Sexagésima. In: Passoni, Célia A. N. Sermões de Padre Antônio Vieira. São Paulo: Núcleo, 1994.

Vieira, Roberta. Argumentação jurídica, persuasão e metáfora. Jusbrasil, 2015. Disponível em: https://robertavieira3705.jusbrasil.com.br/artigos/284606892/ argumentacao-juridica-persuasao-e-metafora. Acesso em: 8 fevereiro 2019.

Recebido em 18 de janeiro de 2021.

Aprovado em 15 de junho de 2021. 


\section{Resumo}

Por entre metáforas: um estudo comparado entre o Sermão da sexagésima e o sermão Pecadores nas mãos de um Deus irado

\section{Francisco Pereira Smith Júnior e Tiane Silva de Sousa}

O presente estudo, por meio da perspectiva da literatura comparada, propõe-se a confrontar os textos literários Sermão da sexagésima, de Padre Antônio Vieira, e Pecadores nas mãos de um Deus irado, de Jonathan Edwards, no intuito de evidenciar pontos de aproximação e de distanciamento no referente ao uso da metáfora como um dos principais recursos persuasivos utilizados pelos autores. Na análise das obras, empreendeu-se a investigação em dois sentidos, o primeiro referente à estrutura textual, que nos permitiu identificar o modo como as metáforas estão dispostas nos textos, os elementos a partir dos quais são construídas, assim como sua relação com trechos ou passagens bíblicas; já o segundo diz respeito a consideração do texto nas suas relações com o contexto histórico, social e cultural, que nos permitiu não somente compreender o modo como as metáfora se estruturam e produzem sentido no nível interno das obras, mas também o porquê de terem sido utilizadas da forma como foram. Para a realização deste trabalho, recorremos a autores como Carvalhal (2006a; 2006b), Machado e Pageaux (2001), Marsden (2015), Massaud Moisés (2008), entre outros.

Palavras-chave: literatura comparada, sermão, deus, metáfora. 